\title{
IMPLIKASI PSIKOLOGI PERKEMBANGAN TERHADAP PENDIDIKAN ANAK USIA DINI
}

\author{
Oleh: \\ Muawanah \\ STABN Sriwijaya Tangerang Banten \\ punyamuawanah@gmail.com
}

\begin{abstract}
ABSTRAK
Tujuan implikasi psikologi perkembangan terhadap pendidikan anak usia dini adalah dapat memberikan rangsangan atau stimulasi pendidikan yang sesuai dengan tahap tumbuh kembang anak usia pra sekolah. Pendidikan anak usia dini merupakan salah satu bentuk penyelenggaraan pendidikan yang menitikberatkan pada peletakan dasar ke arah pertumbuhan dan perkembangan fisik, kecerdasan, sosio emosional, bahasa dan komunikasi, sesuai dengan keunikan dan tahap-tahap perkembangan yang dilalui oleh anak usia dini. Adapun implikasi psikologi perkembangan terhadap pendidikan anak usia dini adalah sebagai berikut: (1) terhadap pengembangan kurikulum; (2) sistem pembelajaran; dan (3) sistem penilaian. Metode yang digunakan dalam penulisan ini adalah metode penelitian kualitatif deskriptif studi kepustakaan. Diharapkan dengan psikologi perkembangan maka bisa menjadikan proses pendidikan pada pendidikan anak usia dini dapat berkembang dengan baik.
\end{abstract}

Kata kunci: Implikasi, Psikologi Perkembangan, Pendidikan Anak Usia Dini.

\section{ABSTRACT}

The aim of the developmental psychological implication of early childhood education is to be able to provide educational stimuli that are appropriate to the stage of development of preschool children. Early chilhood education is one from of education which focuses on laying the foundation towards growth and physical development, intelligence, socioemotional, language and communication in accordance whith the uniqueness and developmental stages that are passed by early childhood. The psychological implications of development for early childhood education are as follows: (1) against curriculum development; (2) learning system; and (3) assessment system. The method used in this paper is descriptive qualitative research methods of library research. It is expected that developmental psychologi can becomes a process of education in early childhood education in early childhood education and then develop well.

Keywords: Implication, Developmental psychology, childhood education.

\section{PENDAHULUAN}

Pendidikan merupakan investasi dalam pengembangan sumber daya manusia dan dipandang sebagai kebutuhan dasar bagi masyarakat yang ingin maju. Menurut undang-undang Republik Indonesia Nomor 20 Tahun 2003 
tentang Sistem Pendidikan Nasional Pasal 1 ayat 1 "Pendidikan adalah usaha sadar dan terencana untuk mewujudkan suasana belajar dan proses pembelajaran agar peserta didik secara aktif mengembangkan potensinya untuk memiliki kekuatan spiritual keagamaan, pengendalian diri, kepribadian, kecerdasan, akhlak mulia serta keterampilan yang diperlukan dirinya, masyarakat, bangsa, dan negara".

Tujuan pendidikan adalah menciptakan seseorang yang berkualitas dan berkarakter sehingga memiliki pandangan yang luas kedepan untuk mencapai suatu cita- cita yang di harapkan dan mampu beradaptasi secara cepat dan tepat di dalam berbagai lingkungan. Karena pendidikan itu sendiri memotivasi diri setiap manusia untuk lebih baik dalam segala aspek kehidupan. Pendidikan adalah merupakan aset penting bagi kemajuan sebuah bangsa, oleh karena itu setiap warga negara harus dan wajib mengikuti jenjang pendidikan, baik jenjang pendidikan anak usia dini, pendidikan dasar, pendidikan menengah maupun tinggi. Dalam bidang pendidikan seorang anak dari lahir memerlukan pelayanan yang tepat dalam pemenuhan kebutuhan pendidikan disertai dengan pemahaman mengenai karakteristik anak sesuai pertumbuhan dan perkembangannya akan sangat membantu dalam menyesuaikan proses belajar bagi anak dengan usia, kebutuhan, dan kondisi masing-masing, baik secara intelektual, emosional, dan sosial.

Pendidikan memiliki jenis dan jenjang tersendiri. Salah satu bagian dari pendidikan adalah Pendidikan Anak Usia Dini (PAUD). Pendidikan anak usia dini (PAUD) adalah jenjang pendidikan sebelum jenjang pendidikan dasar yang merupakan suatu upaya pembinaan yang ditujukan bagi anak sejak lahir sampai dengan usia enam tahun yang dilakukan melalui pemberian rangsangan pendidikan untuk membantu pertumbuhan dan perkembangan jasmani dan rohani agar anak memiliki kesiapan dalam memasuki pendidikan lebih lanjut, yang diselenggarakan pada jalur formal, nonformal, dan informal.

PAUD merupakan pendidikan yang berorientasi pada pembelajaran yang berdasarkan permainan (belajar melalui bermain). Yaitu pembelajaran yang berorientasi pada perkembangan yang banyak memberi kesempatan kepada anak untuk dapat belajar dengan cara-cara yang tepat. Pendekatan yang paling tepat adalah pembelajaran yang berpusat pada anak (student center). Pada hakikatnya PAUD adalah pemberian upaya untuk menstimulasi, membimbing, mengasuh, dan menyediakan kegiatan pembelajaran yang akan menghasilkan kemampuan dan keterampilan pada anak, serta upaya untuk memfasilitasi pertumbuhan dan perkembangan anak. Sebagaimana dalam Undang-Undang Nomor 20 Tahun 2003 tentang Sistem Pendidikan Nasional yaitu bahwa "Tujuan Pendidikan Anak Usia Dini adalah untuk membantu dalam mengembangkan potensi-potensi yang ada pada diri anak".

Psikologi perkembangan adalah bidang psikologi yang mempelajari perkembangan manusia dan faktor-faktor yang membentuk perilaku seseorang sejak lahir sampai kematian. Psikologi perkembangan berkait erat dengan pendidikan, karena dalam dunia pendidikan terbagi dalam berbagai jenjang dan tempo perkembangan sesuai dengan tahap perkembangan hidup manusia. 
Mempelajari psikologi perkembangan tidak hanya berguna bagi orang tua dan guru dalam memberikan pendidikan kepada anak sesuai dengan tahap perkembangannya, tapi juga berguna ketika memahami diri sendiri.

Psikologi perkembangan memberikan wawasan soal sejarah perjalanan hidup sejak bayi, anak-anak, remaja, dewasa, usia lanjut, sampai kematian. Lebih dari itu, psikologi perkembangan juga berguna bagi pengambilan kebijaksanaan dalam merumuskan program bantuan untuk anak dan remaja. Seiring dengan perkembangan masyarakat kontemporer yang ditandai dengan perubahan yang cepat dalam berbagai dimensi kehidupan individu, psikologi perkembangan perlahan-lahan dirasakan manfaatnya di masyarakat, terutama dunia pendidikan khususnya Pendidikan Anak Usia Dini (PAUD). Oleh karena itu, dibutuhkan pemahaman tentang psikologi perkembangan. Dengan adanya realita tersebut, penulis mengangkat judul "Implikasi Psikologi Perkembangan Terhadap Pendidikan Anak Usia Dini".

\section{Implikasi}

\section{KAJIAN TEORI}

Seringkali orang mengunakan istilah implikasi tanpa benar-benar memikirkan apa arti dan definisinya. Penggunaan kata implikasi memang masih jarang digunakan dalam kalimat-kalimat percakapan sehari-hari. Penggunaan kata implikasi biasanya umum digunakan dalam sebuah bahasa penelitian. Maka dari itu masih sedikit kajian yang membahas tentang arti dari kata implikasi. Namun jika mendengar istilah implikasi, hal pertama yang terpikirkan pada umumnya adalah sebuah akibat atau sesuatu hal yang memiliki dampak secara langsung.

Arti kata implikasi itu sendiri sesungguhnya memiliki cakupan yang sangat luas dan beragam, sehingga dapat digunakan dalam berbagai kalimat dalam cakupan bahasa yang berbeda-beda. Kata implikasi dapat dipergunakan dalam berbagai keadaan maupun situasi yang mengharuskan seseorang untuk berpendapat atau berargumen. Seperti halnya dalam bahasa penelitian maupun matematika.

Hingga saat ini, masih belum terdapat pembahasan secara lengkap dan menyeluruh mengenai arti dan definisi kata implikasi. Menurut Kamus Besar Bahasa Indonesia (KBBI) arti kata implikasi adalah keterlibatan atau keadaan terlibat. Sehingga setiap kata imbuhan dari implikasi seperti kata berimplikasi atau mengimplikasikan yaitu berarti mempunyai hubungan keterlibatan atau melibatkan dengan suatu hal.

Kata implikasi memiliki persamaan kata yang cukup beragam, diantaranya adalah keterkaitan, keterlibatan, efek, sangkutan, asosiasi, akibat, konotasi, maksud, siratan, dan sugesti. Persamaan kata implikasi tersebut biasanya lebih umum digunakan dalam percakapan sehari-hari. Hal ini karena kata implikasi lebih umum atau cocok digunakan dalam konteks percakapan bahasa ilmiah dan penelitian.

Pengertian implikasi menurut ahli belum ada yang dapat menjelaskannya secara jelas, hal ini dikarenakan cakupan arti implikasi yang 
luas. Menurut para ahli, pengertian implikasi adalah suatu konsekuensi atau akibat langsung dari hasil penemuan suatu penelitian ilmiah. Pengertian lainnya dari implikasi menurut para ahli adalah suatu kesimpulan atau hasil akhir temuan atas suatu penelitian.

\section{Psikologi Perkembangan}

Psikologi perkembangan merupakan cabang ilmu psikologi yang secara umum mempelajari tentang mengapa dan bagaimana seorang manusia mengalami perubahan seiring berjalannya waktu. Pada awal perkembangannya cabang ilmu ini lebih berfokus pada perkembangan bayi dan anak-anak, dan barulah kemudian diperluas kepada remaja, perkembangan menjadi dewasa, proses penuaan, dan akhirnya mencakup seluruh masa hidup manusia.

Desmita (2010: 4) mengatakan bahwa psikologi perkembangan mengkaji perkembangan tingkah laku dan aktivitas mental manusia sepanjang rentang kehidupannya, mulai dari masa konsepsi hingga meninggal dunia. Syamsu Yusuf (2011: 3) mengatakan bahwa psikologi perkembangan merupakan salah satu bidang psikologi perkembangan merupakan salah satu bidang psikologi yang memfokuskan kajian atau pembahasannya mengenai perubahan tingkah laku dan proses perkembangan dari masa konsepsi (pra-natal) sampai mati. Berdasarkan pendapat para ahli tersebut dapat disimpulkan bahwa psikologi perkembangan merupakan cabang ilmu psikologi yang mempelajari tentang perkembangan manusia dari masa konsepsi sampai meninggal dunia.

\section{Pendidikan Anak Usia Dini (PAUD)}

Pendidikan Anak Usia Dini (PAUD) merupakan suatu upaya pembinaan yang dilakukan melalui pemberian rangsangan pendidikan kepada anak sejak lahir sampai dengan berusia enam tahun. PAUD bertujuan untuk membantu pertumbuhan dan perkembangan jasmani dan rohani anak agar memiliki kesiapan dalam memasuki pendidikan lebih lanjut.

M. Hariwijaya (2007:14), mengemukakan bahwa PAUD dapat diartikan sebagai salah satu bentuk jalur pendidikan dari usia 0-6 tahun, yang diselenggarakan secara terpadu dalam satu program pembelajaran agar anak dapat mengembangkan segala guna dan kreativitasnya sesuai dengan karakteristik perkembangannya.

Menurut UU No. 20 Tahun 2003 tentang Sistem Pendidikan Nasional Bab 1, pasal 1, butir 14 dinyatakan bahwa "Pendidikan Anak Usia Dini adalah suatu upaya pembinaan yang ditujukan kepada anak sejak lahir sampai dengan usia enam tahun yang dilakukan melalui pemberian rangsangan pendidikan untuk membantu pertumbuhan dan perkembangan jasmani dan rohani agar anak memiliki kesiapan dalam memasuki pendidikan lebih lanjut".

Sesuai Undang-Undang Nomor 20 Tahun 2003 tentang Sistem Pendidikan Nasional, pada pasal 28 menyebutkan bahwa: (1) Pendidikan anak usia dini diselenggarakan sebelum jenjang pendidikan dasar; (2) Pendidikan anak usia dini dapat diselenggarakan melalui jalur pendidikan formal, 
nonformal, dan/atau informal; (3) Pendidikan anak usia dini pada jalur pendidikan formal berbentuk Taman Kanak-kanak (TK), Raudatul Athfal (RA), atau bentuk lain yang sederajat; dan (4) Pendidikan anak usia dini pada jalur pendidikan nonformal berbentuk Kelompok Bermain (KB), Taman Penitipan Anak (TPA), atau bentuk lain yang sederajat.

Indonesia pada tahun 1990, telah menandatangani sebuah Deklarasi Dunia tentang Pendidikan Untuk Semua (Education for All Declaration) pada konferensi UNESCO, di Thailand. Deklarasi ini menjadi komitmen bersama, untuk menyediakan pendidikan dasar yang bermutu dan non diskriminatif, di masing-masing negara. Realisasi deklarasi tersebut juga sekaligus merupakan upaya untuk memenuhi Hak Pendidikan, bahwa "Setiap orang berhak memperoleh pendidikan. Pendidikan harus cuma-cuma, setidak-tidaknya untuk tingkat sekolah rendah dan pendidikan dasar. Pendidikan dasar diperlukan untuk menjaga perdamaian".

Salah satu pemenuhan hak pendidikan sejak dini pada usia 3-5 tahun yang kemudian dilakukan masyarakat dan pemerintah yaitu program Pendidikan Anak Usia Dini (PAUD). Di dalam pelaksanaannya, setiap kelurahan yang ada di Indonesia didorong untuk memiliki minimal satu PAUD. PAUD merupakan alternatif pemenuhan hak pendidikan selain Taman Kanak-Kanak (TK) atau Taman Pendidikan Alquran (TPA).

Berdasarkan Peraturan Menteri Pendidikan Nasional Nomor 13 Tahun 2005, PAUD termasuk dalam jenis pendidikan Non Formal. Pendidikan Non Formal selain PAUD yaitu Tempat Penitipan Anak (TPA), Play Group dan PAUD Sejenis. PAUD sejenis artinya PAUD yang diselenggarakan bersama dengan program Posyandu (Pos Pelayanan Terpadu untuk kesehatan ibu dan anak). Sedangkan pada Departemen Pendidikan Nasional (Depdiknas), PAUD dimasukkan kedalam program Pendidikan Luar Sekolah (PLS).

Pada penyelenggaraan PAUD, jenis pendidikan ini tidak menggunakan kurikulum baku dari Depdiknas, melainkan menggunakan rencana pengajaran yang disebut Menu Besar. Menu Besar ini mencakup pendidikan moral dan nilai keagamaan, fisik/motorik, bahasa, sosial-emosional dan seni. Panduan dalam Menu Besar ini akan dikembangkan oleh tiap PAUD, berdasarkan kebutuhan dan kemampuan masing-masing PAUD.

Sejak tahun 2016, Kementerian Pendidikan dan Kebudayaan RI mewajibkan setiap anak untuk mengikuti pendidikan anak usia dini (PAUD) setidaknya selama setahun, sebelum masuk jenjang sekolah dasar (SD). PAUD dianggap sebagai tahapan penting bagi perkembangan setiap anak. Prof. Dr. Lydia Freyani Hawadi, Direktur Jenderal Pendidikan Anak Usia Dini, Nonformal dan Informal (PAUDNI), mengatakan bahwa kegiatan di PAUD dapat memberikan rangsangan atau stimulasi pendidikan yang sesuai dengan tahap tumbuh kembang anak usia pra sekolah.

Menurut Prof. Dr. Lydia Freyani Hawadi, pendidikan yang diberikan untuk anak usia 3-6 tahun tidak hanya bertujuan mengenalkan anak pada bidang-bidang pelajaran ataupun melatihnya berinteraksi dengan anak sebaya. Lebih jauh dari itu, PAUD memiliki fungsi utama mengembangkan semua 
aspek perkembangan anak, meliputi perkembangan kognitif, bahasa, fisik (motorik kasar dan halus), sosial dan emosional. Adapun manfaat yang akan dirasakan setelah mendapatkan pendidikan di playgroup atau TK berikut adalah sebagai berikut:

1. Memperkenalkan anak pada dunia sekolah;

2. Membiasakan anak terhadap kegiatan terstruktur;

3. Mengajari anak untuk disiplin dan mengikuti peraturan;

4. Menumbuhkan imajinasi dan kreativitas;

5. Menanamkan nilai-nilai positif; dan

6. Membentuk dasar kepribadian anak.

Menurut Byrnes, pendidikan anak usia dini akan memberikan persiapan anak menghadapi masa-masa ke depannya, yang paling dekat adalah menghadapi masa sekolah. Selanjutnya menurut Byrnes, bahwa pendidikan anak usia dini itu penting, karena di usia inilah anak membentuk pendidikan yang paling bagus. Di usia inilah anak-anak harus membentuk kesiapan dirinya menghadapi masa sekolah dan masa depan. Investasi terbaik yang bisa diberikan untuk anak-anak adalah persiapan pendidikan mereka di usia dini.

Ada dua tujuan mengapa perlu diselenggarakan pendidikan anak usia dini, yaitu:

1. Tujuan utama: untuk membentuk anak yang berkualitas, yaitu anak yang tumbuh dan berkembang sesuai dengan tingkat perkembangannya sehingga memiliki kesiapan yang optimal di dalam memasuki pendidikan dasar serta mengarungi kehidupan di masa dewasa.

2. Tujuan penyerta: untuk membantu menyiapkan anak mencapai kesiapan belajar (akademik) di sekolah.

Menurut Byrnes (Peraih gelar Woman of the Year dari Vitasoy di Australia) di lembaga pendidikan anak usia dini yang bagus, anak-anak akan belajar menjadi pribadi yang mandiri, kuat bersosialisasi, percaya diri, punya rasa ingin tahu yang besar, bisa mengambil ide, mengembangkan ide, pergi ke sekolah lain dan siap belajar, cepat beradaptasi, dan semangat untuk belajar. Sementara, anak yang tidak mendapat pendidikan usia dini, akan lamban menerima sesuatu. Anak-anak yang berpendidikan usia dini tepat memiliki bensin penuh, mesinnya akan langsung jalan begitu ia ada di tempat baru. Sementara anak yang tidak berpendidikan usia dini akan kesulitan memulai mesinnya, jadinya lamban.

\section{PEMBAHASAN}

Pendidikan Anak Usia Dini (PAUD) merupakan salah satu bentuk penyelenggaraan pendidikan yang menitikberatkan pada peletakan dasar ke arah pertumbuhan dan perkembangan fisik (koordinasi motorik halus dan kasar), kecerdasan (daya pikir, daya cipta, kecerdasan emosi, kecerdasan spiritual), sosio-emosional (sikap dan perilaku serta agama) bahasa dan komunikasi, sesuai dengan keunikan dan tahap-tahap perkembangan yang dilalui oleh anak usia dini. 
Tidak bisa dipungkiri bahwa pendidikan anak usia dini merupakan pendidikan yang sangat mendasar dan strategis dalam pembangunan sumber daya manusia. Begitu pentingnya pendidikan ini tidak mengherankan apabila banyak negara menaruh perhatian yang sangat besar terhadap penyelenggaraan pendidikan ini hingga pemerintah Indonesia pun memberikan layanan pendidikan gratis hingga tingkat SMP.

Adapun implikasi psikologi perkembangan dalam pendidikan adalah sebagai berikut :

1. Di dalam perkembangan seorang individu tentunya sebagai pendidik juga harus tahu menempatkan dirinya terhadap perkembangan dengan memberikan metode atau cara pengajaran yang sesuai dengan tahap atau fase perkembangan individu yang akan dididiknya.

2. Dengan memahami psikologi perkembangan, maka akan mengetahui tingkat kemampuan individu dalam setiap fase perkembangannya. Sehingga akan diketahui pada fase perkembangan yang mana seseorang bisa diberi stimulus tertentu.

3. Dengan adanya psikologi perkembangan, maka diharapkan dapat mempersiapkan diri dalam menghadapi perubahan-perubahan yang akan dihadapi oleh setiap individu.

4. Khusus untuk tim pengajar atau guru, dengan memahami psikologi perkembangan ini maka sudah pasti dapat memberikan pengajaran yang sesuai dengan usia anak didiknya.

5. Dengan memahami psikologi perkembangan, maka dapat mempelajari karakteristik umum perkembangan peserta didik, baik secara fisik, kognitif, maupun psiko-sosial dalam segala aspek pendidikan anak atau individu tersebut.

6. Dengan memahami psikologi perkembangan, dapat mempelajari perbedaan-perbedaan yang bersifat pribadi pada tahapan, fase, atau pada masa perkembangan tertentu.

7. Dengan memahami dan menerapkan psikologi perkembangan, maka dapat mempelajari tingkah laku seorang anak atau seorang individu pada lingkungan tertentu yang menimbulkan reaksi yang berbeda pula satu dengan yang lainnya.

8. Dengan adanya psikologi perkembangan, maka dapat mempelajari penyimpangan tingkah laku yang dialami oleh seseorang seperti kenakalan, kelainan-kelainan, dan juga fungsional inteleknya.

9. Dengan memahami psikologi perkembangan, maka diharapkan setiap individu yang memang masih mengalami perkembangan dapat mencari pedoman yang terbaik baginya, baik secara psikis maupun mental dan juga dari aspek sosialnya.

10. Dengan adanya psikologi perkembangan dan dengan menerapkannya di dalam pendidikan, maka diharapkan pengajar maupun orang tua dapat memberikan cara untuk menghadapi segala perubahan yang terjadi pada setiap fase pertumbuhan yang ada pada seseorang. 
Selain itu, implikasi psikologi perkembangan terhadap pendidikan dapat diuraikan sebagai berikut: (1) terhadap pengembangan kurikulum; (2) sistem pembelajaran; dan (3) sistem penilaian.

1. Kontribusi Psikologi Perkembangan terhadap pengembangan kurikulum. Kajian psikologi perkembangan dalam kaitannya dengan pengembangan kurikulum pendidikan terutama berkenaan dengan pemahaman aspekaspek perilaku dalam konteks belajar mengajar. Terlepas dari berbagai aliran Psikologi yang mewarnai pendidikan, pada intinya pembahasan psikologi ini memberikan perhatian terhadap bagaimana input dan output pendidikan dapat berjalan dengan tidak mengabaikan aspek perilaku dan kepribadian peserta didik. Secara Psikologis, manusia merupakan individu yang unik. Dengan demikian, kajian psikologi dalam pengembangan kurikulum sesungguhnya memperhatikan keunikan yang dimiliki oleh setiap individu, baik ditinjau dari tingkat kecerdasan, kemampuan sikap, motivasi, perasaan serta karakteristik-karakteristik individu lainnya. Kurikulum pendidikan sesungguhnya mampu menyediakan kesempatan kepada setiap individu untuk dapat berkembang sesuai dengan potensi yang dimilikinya, baik dalam hal pokok masalah maupun metode penyampaiannya. Secara khusus, dalam konteks pendidikan di Indonesia saat ini, kurikulum yang dikembangkan adalah kurikulum berbasis kompetensi, yang pada intinya menekankan pada upaya pengembangan pengetahuan, keterampilan dan nilai-nilai dasar yang refleksikan dalam kebiasaan berpikir dan bertindak secara konsisten dan terus menerus memungkinkan seseorang menjadi kompeten, dalam arti memiliki pengetahuan dan nilai-nilai dasar untuk melakukan sesuatu. Dengan demikian dalam pengembangan kurikulum berbasis kompetensi, kajian psikologi terutama berkenaan dengan aspek-aspek: (a) kemampuan siswa melakukan sesuatu dalam berbagai konteks; (b) Pengalaman belajar siswa; (c) hasil belajar (learning outcomes); dan (d) standarisasi kemampuan siswa.

2. Kontribusi Psikologi Perkembangan terhadap sistem pembelajaran. Kajian psikologi perkembangan telah melahirkan berbagai teori yang mendasari sistem pembelajaran. Ada sejumlah teori dalam pembelajaran, seperti teori classical conditioning, connectionism, operant conditioning, gestalt, teori daya, teori kognitif dan teori-teori pembelajaran lainnya. Terlepas dari kontroversi yang menyertai kelemahan dari masing-masing teori tersebut, pada kenyataannya teori tersebut telah teruji. Di samping itu, kaitan psikologi perkembangan telah melahirkan pula sejumlah prinsip-prinsip yang melandasi pembelajaran. Nasution (Daeng Sudiworo, 2002) mengatakan 12 prinsip dalam belajar, yakni: (a) agar seseorang benarbenar belajar, harus memiliki suatu tujuan; (b) tujuan itu harus timbul dari atau berhubungan dengan kebutuhan hidupnya dan bukan karena dipaksakan orang lain; (c) orang itu harus bersedia mengalami bermacammacam kesulitan dan berusaha dengan tekun untuk mencari tujuan yang berharga baginya; (d) belajar itu harus terbukti dari perubahan kelakuannya; (e) selain tujuan pokok yang hendak dicapai, diperoleh pula 
hasil sambilan; (f) belajar lebih berhasil dengan jalan berbuat dan melakukan; (g) seseorang belajar sebagai keseluruhan, tidak hanya aspek intelektual namun termasuk pula aspek emosional, sosial, etis; (h) seseorang memerlukan bantuan dan bimbingan dari orang lain; (i) di samping mengejar tujuan belajar yang sesungguhnya, seseorang juga harus mengejar tujuan-tujuan yang lain; (j) belajar lebih berhasil, apabila usaha itu lebih memberi sukses yang menyenangkan; (k) ulangan dan latihan memang perlu, tetapi harus didahului dengan pemahaman yang mendasar; dan (l) belajar hanya mungkin kalau ada kemauan dan hasrat untuk belajar.

3. Penilaian sistem pendidikan merupakan salah satu aspek penting dalam pendidikan guna memahami seberapa jauh tingkat keberhasilan pendidikan. Melalui kajian psikologis, dapat memahami seberapa jauh tingkat keberhasilan pendidikan, dapat memahami perkembangan perilaku apa saja yang diperoleh peserta didik setelah mengikuti kegiatan pendidikan atau pembelajaran tertentu. Di samping itu kajian psikologis telah memberikan sumbangan nyata dalam pengukuran potensi-potensi yang dimiliki oleh setiap peserta didik, terutama setelah dikembangkannya berbagai test psikologis, baik untuk mengukur tingkat kecerdasan, bakat maupun kepribadian individu lainnya. Dikenal sejumlah test psikologis yang saat ini masih banyak digunakan untuk mengukur potensi seorang individu, seperti test Multiple Appitude Test (MAT), Differensial Appitude Test (DAT), EPPS dan alat ukur lainnya. Pemahaman kecerdasan bakat, minat dan aspek kepribadian lainnya melalui pengukuran psikologis, memiliki arti penting dalam upaya pengembangan proses pendidikan individu yang bersangkutan sehingga pada gilirannya dapat dicapai perkembangan individu yang optimal. Oleh karena itu, betapa pentingnya penguasaan psikologi perkembangan

Piaget sebagai salah satu tokoh yang mencetuskan mengenai teori perkembangan kognitif pada anak telah menjelaskan bahwa anak usia prasekolah berada pada tahapan praoperasional. Tahapan praoperasional ini memungkinkan anak untuk melakukan representasi melalui kata-kata, gambar dan bayangan. Mereka didominasi oleh pola egosentris dan juga keyakinan magis. Piaget menjelaskan secara lebih rinci mengenai tahap perkembangan ini sehingga kemudian ada beberapa hal yang patut diperhatikan ketika pendidikan prasekolah akan diadakan. Berikut adalah beberapa macam penjelasannya:

1. Pembuatan kurikulum sederhana

Kurikulum yang perlu disusun dalam pendidikan prasekolah harus disesuaikan sedemikian rupa sehingga tetap sederhana dan tidak terlalu kompleks. Pada dasarnya pendidikan prasekolah sifatnya hanya untuk menyiapkan anak-anak usia prasekolah untuk mulai mengenal dunia pendidikan. Mereka akan dikenalkan dengan lingkungan sosialnya sehingga mampu menjadi lebih paham mengenai hal-hal menarik yang ada di sekitarnya. 
2. Menghindari kompetensi yang bersifat operasional konkret

Kompetensi anak-anak pada masa usia prasekolah terbatas pada tahapan praoperasional. Ini harus disadari sebagai bahan kajian, di mana pendidikan usia prasekolah hendaknya tidak memaksa anak-anak untuk cepat menyelesaikan masalah hitung-hitungan yang kompleks, cara membaca yang kompleks dan lain sebagainya. Pada periode ini, anak hanya butuh mengenal bagaimana cara-cara dasar untuk membaca atau berhitung.

3. Pendekatan egosentris dalam pendidikan

Mengingat dalam tahapan usia prasekolah dominasi sikap egosentris anak masih tinggi, maka seorang pendidik dalam pendidikan prasekolah harus menyadari bahwa anak bukanlah miniatur orang dewasa. Anak mungkin akan cenderung lebih banyak mengatakan tidak dan susah diatur. Namun justru ini menjadi tantangan tersendiri untuk bisa "memanipulasi" apa yang menjadi tujuan utama kepada anak.

4. Penggunaan bahasa-bahasa sederhana

Bahasa-bahasa yang sederhana bisa digunakan sebagai bagian dari proses pendidikan prasekolah. Melalui penggunaan bahasa yang mudah dipahami oleh anak, anak bisa belajar banyak mengenai apa yang semestinya mereka lakukan dan tidak lakukan. Penggunaan bahasa yang terlalu kompleks mungkin akan membuat anak justru tidak tercapai kompetensinya.

5. Pembelajaran yang mengutamakan audio visual

Sebagaimana telah dijelaskan sebelumnya, tahapan praoperasional juga cenderung membuat anak melakukan representasi melalui gambar dan kata-kata. Mereka juga bisa membayangkan suatu benda tetapi tidak terlalu kompleks dan lebih dipengaruhi oleh unsur magis. Benda-benda di sekitar mereka dianggap bisa hidup dan berinteraksi. Oleh karenanya, pembelajaran dengan audio visual menjadi lebih tepat untuk diterapkan.

6. Penentuan penilaian yang tepat

Implikasi psikologi perkembangan terhadap pendidikan prasekolah selanjutnya yaitu mengenai penentuan sistem penilaian yang tepat. Seorang pengajar tidak akan melakukan penilaian hanya berdasarkan keaktifan siswa, akan tetapi lebih pada pengamatan bagaimana anak bisa memahami konsep baru yang ia dapat.

7. Sistem pembelajaran yang menyenangkan

Anak usia prasekolah suka dengan hal-hal yang menyenangkan. Mereka akan lebih termotivasi ketika mendapatkan suasana yang menyenangkan selama proses pembalajaran. Oleh karenanya, dalam pendidikan prasekolah akan lebih banyak aktivitas seperti bernyanyi, menari atau bercerita.

8. Tidak menghilangkan kesempatan bermain anak

Usia prasekolah ada periode transisi dari masa bermain anak-anak kepada masa untuk sekolah. Oleh karenanya pendidikan prasekolah juga perlu dipersiapkan dengan tidak menghilangkan kesempatan bermain anak. Tak 
heran jika kemudian bisa melihat pendidikan di tingkat Taman Kanakkanak selalu dilengkapi dengan fasilitas bermain yang lengkap.

9. Menyiapkan anak pada masa transisi

Pendidikan prasekolah juga berfungsi untuk menyiapkan anak pada masa transisi. Masa ini merupakan kunci keberhasilan seorang anak dalam memasuki dunia pendidikan yang sebenarnya. Oleh karenanya, dasar membaca dan berhitung diberikan tetapi tidak diikuti dengan cara penyelesaian atau pemecahan masalah yang kompleks.

10. Berfokus pada dunia anak

Pendidikan prasekolah juga hendaknya berfokus pada dunia anak. Ingat, anak usia prasekolah masih sering membayangkan mereka berada dalam dunianya yang penuh dengan keajaiban. Oleh karenanya situasi yang mendukung juga diperlukan tetapi juga diarahkan untuk menyiapkan anak pada tahap perkembangan selanjutnya.

Jadi berdasarkan penjelasan tersebut, ada implikasi yang cukup bagus dengan adanya psikologi perkembangan di dalam pendidikan anak usia dini (prasekolah). Dengan masuknya psikologi perkembangan akan banyak terdapat penyesuaian-penyesuian tersebut yang bisa menjadikan proses pendidikan kemudian berkembang dengan baik.

\section{PENUTUP}

Pendidikan merupakan usaha sadar dan terencana untuk mewujudkan suasana belajar dan proses pembelajaran agar peserta didik secara aktif mengembangkan potensi dirinya untuk memiliki kekuatan spiritual keagamaan, pengendalian diri, kepribadian, kecerdasan, akhlak mulia, serta keterampilan yang diperlukan dirinya dan masyarakat. psikologi perkembangan merupakan cabang ilmu psikologi yang mempelajari tentang perkembangan manusia dari masa konsepsi sampai meninggal dunia. Pendidikan Anak Usia Dini (PAUD) merupakan suatu upaya pembinaan yang dilakukan melalui pemberian rangsangan pendidikan kepada anak sejak lahir sampai dengan berusia enam tahun. PAUD bertujuan untuk membantu pertumbuhan dan perkembangan jasmani dan rohani anak agar memiliki kesiapan dalam memasuki pendidikan lebih lanjut. Tujuan implikasi psikologi perkembangan terhadap pendidikan anak usia dini adalah dapat memberikan rangsangan atau stimulasi pendidikan yang sesuai dengan tahap tumbuh kembang anak usia pra sekolah. Adapun implikasi psikologi perkembangan terhadap pendidikan anak usia dini adalah sebagai berikut: (1) terhadap pengembangan kurikulum; (2) sistem pembelajaran; dan (3) sistem penilaian. Oleh karena itu dengan adanya psikologi perkembangan, maka apabila akan mengadakan pendidikan anak usia dini harus memperhatikan hal-hal sebagai berikut: (1) Pembuatan Kurikulum yang Sederhana; (2) Menghindari Kompetensi yang Bersifat Operasional Konkret; (3) Pendekatan Egosentris dalam Pendidikan; (4) Penggunaan Bahasa-bahasa Sederhana; (5) Pembelajaran yang Mengutamakan Audio Visual; (6) Penentuan Penilaian yang Tepat; (7) Sistem Pembelajaran yang Menyenangkan; (8) Tidak Menghilangkan 
Kesempatan Bermain Anak; (9) Menyiapkan Anak pada Masa Transisi; dan (10) Berfokus pada Dunia Anak. Ada implikasi yang cukup bagus dengan adanya psikologi perkembangan di dalam pendidikan anak usia dini (prasekolah). Dengan masuknya psikologi perkembangan akan banyak terdapat penyesuaian-penyesuian tersebut yang bisa menjadikan proses pendidikan kemudian berkembang dengan baik.

\section{DAFTAR PUSTAKA}

Depdiknas. 2003. UU RI No. 20 Tahun 2003 tentang Sistem Pendidikan Nasional. Jakarta: Depdiknas. 2005. Standar Nasional Pendidikan. Jakarta: Depdiknas.

Dewantara, Ki Hadjar. 1977. Karya Ki Hadjar Dewantara Bagian Pertama: Pendidikan. Yogyakarta: Majelis Luhur Persatuan Taman Siswa.

Hidayat, H. Syarif. 2013. Teori dan Prinsip Pendidikan. Tangerang: Pustaka Mandiri.

Imron, Ali. 2013. Proses Manajemen Tingkat Satuan Pendidikan. Jakarta: Bumi Aksara.

Imron, Ali. 2012. Kebijakan Pendidikan di Indonesia Proses, Produk, dan Masa Depannya. Jakarta: Bumi Aksara.

Kementerian Pendidikan dan Kebudayaan. 2016. Kamus Besar Bahasa Indonesia (Edisi Kelima). Jakarta: Badan Pengembangan dan Pembinaan Bahasa.

paud-dikmas.kemdikbud.go.id/segment/19.html.id.theasianparent.com/10manfaat-anak-sekolahpaud/2/health.detik.com/ read/2013/05/21/182853/2252243/1301/ini -alasan-mengapa-paud-penting-bagi-perkembangan-anakpaudanakbermainbelajar.blogspot.co.id/2012/11/pengertian-dan-konsepdasar-paud.html (Diakses pada 21 November 2016).

Direktorat Pendidikan Anak Usia Dini, Depdiknas. 2007. Kerangka Dasar Kurikulum Pendidikan Anak Usia Dini. Jakarta: Universitas Negeri Jakarta.

Hariwijaya, M. dan Bertiani Eka Sukaca. 2007. PAUD Melejitkan Potensi Anak dengan Pendidikan Sejak Dini. Bandung: IKIP Bandung.

Solehuddin, M. 1997. Konsep Dasar Pendidikan Prasekolah. Bandung: IKIP Bandung.

Partini. 2010. Pengantar Pendidikan Anak Usia Dini. Yogyakarta: Grafindo Lentera Media.

Sujiono, Yuliana Nurani. 2011. Konsep Dasar Pendidikan Anak Usia Dini. Jakarta: PT.Indeks. 